\title{
Pengaruh Model Pembelajaran Project Based Learning Melalui Percobaan Sederhana Terhadap Kompetensi Pengetahuan IPA
}

\author{
Ni Luh Sri Apsari $1^{*}$ I Wyn Wiarta ${ }^{2}$ \\ ${ }^{12}$ Prodi Pendidikan Guru Sekolah Dasar, Universitas Pendidikan Ganesha, Indonesia
}

\author{
A R T I C LE I NFO \\ Article history: \\ Received 18 Desember \\ 2019 \\ Received in revised form \\ 30 Desember 2019 \\ Accepted 15 Januari 2020 \\ Available online 20 \\ Februari 2020 \\ Kata Kunci: \\ project based learning \\ percobaan sederhana \\ kompetensi pengetahuan \\ IPA. \\ Keywords: \\ project based learning \\ simple experiments, science \\ knowledge competencies
}

\begin{abstract}
A B S T R A K
Penelitian ini bertujuan untuk mengetahui pengaruh model pembelajaran Project Based Learning melalui percobaan sederhana terhadap kompetensi pengetahuan IPA kelas IV SD Gugus I Mengwi . Penelitian ini merupakan jenis penelitian eksperimen semu dengan rancangan nonequivalent control group design. Populasi dalam penelitian ini adalah seluruh kelas IV SD Negeri di Gugus 1 Mengwi sebanyak 187 siswa. Sampel ditentukan dengan teknik random sampling. Sampel dalam penelitian ini adalah kelas IV SD No. 1 Pererenan sebanyak 32 siswa sebagai kelompok eksperimen dan kelas IV SD No. 1 Cemagi sebanyak 30 siswa sebagai kelompok kontrol. Data tentang kompetensi pengetahuan IPA dikumpulkan dengan instrumen berupa tes objektif. Berdasarkan hasil analisis uji-t data GSn, diperoleh thitung $=5,139$, pada pada taraf signifikansi $5 \%$ dengan $d k=32+30-2=60$ dan diperoleh tabel $=2,000$. Sehingga dapat diketahui bahwa thitung $=5,139>t_{\text {tabel }}=2,000$ yang berarti $\mathrm{H}_{0}$ ditolak. Berdasarkan hasil analisis tersebut, diketahui bahwa ratarata data GSn kompetensi pengetahuan IPA siswa pada kelompok eksperimen lebih dari nilai rata-rata pada kelompok kontrol yaitu $X_{1}=0,45>X_{2}=0,32$. Jadi, terdapat pengaruh yang signifikan model pembelajaran Project Based Learning melalui percobaan sederhana terhadap kompetensi pengetahuan IPA kelas IV SD Gugus I Mengwi.
\end{abstract}

\section{A B S T R A C T}

This study was aimed to determine the effect of Project Based Learning model through a simple experiment on science knowledge competencies of fourth grade elementary school at SD Gugus I Mengwi in 2018/2019 academic year. This research was a quasi-experimental study with nonequivalent control group design. The population in this study were all fourth grade public elementary schools at SD Gugus I Mengwi in 2018/2019 academic year with 187 total students. The sample was determined by random sampling technique. The sample in this study was fourth grade students at SD No. 1 Pererenan as many as 32 students as the experimental group and fourth grade students at SD No. 1 Cemagi as many as 30 students as a control group. Data on science knowledge competencies were collected through instruments in form of ordinary multiple-choice objective tests. Based on the results of the $t$-test analysis of the GSn data, it was obtained $t=$ 5.139 and $t$ table $=2,000$ on $5 \%$ of significance level with $d k=32+30-2=60$. So, it can be seen that tcount $=5.139>t$ table $=2,000$ which meant Ho was rejected. Based on the results of the analysis, it was known that the average of GSn data of science competency knowledge of the students in the experimental group was more than the average value in the control group, called X1 =0.45> X2 =0.32. Thus, it can be concluded that there was a significant effect of Project Based Learning learning model through a simple experiment on science knowledge competencies of fourth grade syudents at $S D$ Gugus I Mengwi in 2018/2019 academic year.

Copyright (C) Universitas Pendidikan Ganesha. All rights reserved.

\section{Pendahuluan}

Berbagai upaya perbaikan terus dilakukan pemerintah untuk meningkatkan mutu pendidikan. Upaya-upaya tersebut antara lain penetapan Undang-undang Nomor 20 Tahun 2003 tentang sistem Pendidikan Nasional, penyempurnaan kurikulum, penyediaan sarana dan prasarana pendidikan, penyelenggaraan pelatihan dan memberikan kesempatan beasiswa bagi guru-guru untuk melanjutkan studi ke jenjang pendidikan yang lebih tinggi serta adanya program kelompok kerja kepala sekolah (K3S) untuk mendiskusikan tentang administrasi guru, menyusun tes akhir semester, sosialisasi melalui seminar atau lokakarya pembelajaran, dan sebagainya.

\footnotetext{
${ }^{1}$ Corresponding author.

E-mail addresses: luh.sri.apsari@undiksha.ac.id¹(Apsari),iwayan.wiarta@undiksha.ac.id'1(Wiarta)
} 
Pendidikan merupakan usaha sadar secara berencana yang dilakukan oleh orang dewasa untuk mendewasakan seseorang (peserta didik). Undang-Undang RI Nomor 20 Tahun 2003 tentang Sistem Pendidikan Nasional mendefinisikan pendidikan sebagai berikut. Pendidikan adalah usaha sadar dan terencana untuk mewujudkan suasana belajar dan proses belajar agar peserta didik secara aktif mengembangkan potensi dirinya untuk memiliki kekuatan spiritual keagamaan, pengendalian diri, kepribadian, kecerdasan, ahlak mulia serta keterampilan yang diperlukan dirinya, masyarakat, bangsa dan negara.

Sedangkan, menurut Badar (2014:1) "pendidikan adalah salah satu bentuk perwujudan kebudayaan manusia yang dinamis dan sarat perkembangan". Dengan kata lain, pendidikan diharapkan dapat mewujudkan manusia yang baik dalam seluruh dimensi kehidupan yang mampu mengisi hidupanya secara produktif untuk kepentingan dirinya dan masyarakat. Pendidikan memiliki kekuatan (pengaruh) yang dinamis dalam kehidupan manusia di masa depan. Pendidikan bertujuan untuk mengembangkan berbagai potensi yang dimiliki secara optimal, seperti pengembangan potensi intelektual, emosional, sosial dan spiritual, sesuai dengan tahap perkembangan serta karakteristik lingkungan fisik dan lingkungan sosial budaya di mana pun dia berada. Oleh karena itu, pentingnya peran pendidikan harus direncanakan dan dilaksanakan dengan sebaik-baiknya, sehingga apa yang menjadi tujuan dari pendidikan tersebut dapat tercapai secara optimal.

Keberhasilan suatu pendidikan tidak terlepas dari proses pembelajaran di sekolah. Pembelajaran merupakan suatu proses atau upaya menciptakan kondisi belajar dalam mengembangkan kemampuan minat dan bakat siswa secara optimal, sehigga tujuan pembelajaran dapat tercapai. Proses pembelajaran dapat dianggap sebagai suatu sistem. Karena keberhasilannya dapat ditentukan oleh berbagai komponen yang membentuk sistem itu sendiri. Apabila dipetakan, terdapat banyak komponen yang berpengaruh terhadap proses dan pencapaian kompetensi, mulai dari komponen yang datang dari dalam, yang secara langsung berkaitan dengan proses pembelajaran, sampai pada komponen luar yang tidak langsung berkaitan dengan proses pembelajaran. Diantara sekian banyak komponen yang berpengaruh itu, salah satu komponen yang dimaksud adalah kurikulum. Kurikulum memegang peranan yang sangat penting dalam proses pembelajaran. Kurikulum yang diterapkan akan menjadi pedoman dalam pelaksanaan pembelajaran. Undang-Undang Nomor 20 Tahun 2003 menyatakan, "kurikulum adalah seperangkat rencana dan pengaturan mengenai tujuan, isi, dan bahan pelajaran serta cara yang digunakan sebagai pedoman penyelenggaraan kegiatan pembelajaran untuk mencapai tujuan pendidikan tertentu". Menurut Daryanto (2014:1) "kurikulum adalah suatu respon pendidikan terhadap kebutuhan masyarakat dan bangsa dalam mebangun generasi muda bangsanya”.

Kurikulum yang diterapkan saat ini adalah Kurikulum 2013 yang merupakan penyempurnaan dari Kurikulum Tingkat Satuan Pendidikan (KTSP). Daryanto dan Sudjendro (2014:17) menyatakan, Perubahan kurikulum KTSP menjadi Kurikulum 2013 di Indonesia bertujuan untuk mempersiapkan insan Indonesia untuk memiliki kemampuan hidup sebagai pribadi dan warga negara yang beriman, produktif, kreatif, inovatif, dan afektif serta mampu berkontribusi dalam kehidupan bermasyarakat, berbangsa, bernegara dan peradaban dunia melalui penguatan; sikap, keterampilan, dan pengetahuan yang terintegrasi.

Ciri utama dari kurikulum 2013 adalah lebih menekankan pada penanaman pendidikan karakter bagi siswanya. Dalam kurikulum 2013 siswa dituntut melalui beberapa proses secara aktif mencari, mengolah, mengkonstruksi, dan menerapkan pengetahuan. Selain itu, dalam kurikulum 2013 siswa juga dituntut untuk lebih aktif dalam hal menemukan dan menggali pengetahuannya sendiri. Pembelajaran seperti ini biasa disebut dengan student centered (pembelajaran berpusat pada siswa). Namun, dalam pembelajaran yang mengimplementasikan kurikulum 2013, dimana student centered bukan berarti guru tidak mempunyai peran sama sekali dalam pembelajaran. Guru tetap berperan sebagai pendidik, pengajar, pembimbing, pengarah, pelatih, penilai, dan pengevaluasi untuk siswa.

Penyelenggaraan pendidikan di Indonesia bagi siswanya, ditetapkan ke dalam jenjang-jenjang pendidikan salah satunya adalah pendidikan sekolah dasar. Pendidikan sekolah dasar bukan hanya memberi bekal kemampuan intelektual dasar dalam membaca, menulis, dan berhitung saja, melainkan juga sebagai proses mengembangkan kemampuan dasar peserta didik secara optimal dalam aspek intelektual, sosial, dan personal. Tujuan pendidikan di SD mencakup pembentukan dasar kepribadian siswa sebagai manusia Indonesia seutuhnya sesuai dengan tingkat perkembangan dirinya, pembinaan pemahaman dasar dan seluk-beluk ilmu pengetahuan dan teknologi sebagai landasan untuk belajar pada jenjang pendidikan yang lebih tinggi dan hidup dalam masyarakat.

Pendidikan di SD membelajarkan berbagai mata pelajaran kepada siswanya, salah satunya adalah Ilmu Pengetahuan Alam (IPA). IPA mempelajari peristiwa-peristiwa yang terjadi di alam. "IPA merupakan rumpun ilmu, memiliki karakteristik khusus yaitu mempelajari fenomena alam yang faktual (factual), baik 
berupa kenyataan (reality), atau kejadian (events) dan hubungan sebab akibatnya (Wisudawati dan Sulistyowati, 2015:22). Pembelajaran IPA di SD memuat materi tentang pengetahuan-pengetahuan alam yang dekat dengan kehidupan siswa SD. Dalam proses pembelajaran IPA, siswa juga harus mampu mengemas pembelajaran yang sesuai dengan kebutuhan dan kemampuanya. Sehingga, berdasarkan hal tersebut perlu diciptakan suasana pembelajaran IPA yang dapat mendorong minat dan belajar serta mempermudah pemahaman siswa memahami materi yang diajarkan. Siswa SD yang masih berada pada tahap operasional konkret sebaiknya disajikan pembelajaran yang mengedepankan objek-objek nyata sebagai media pembelajarannya. Selain itu, untuk mempercepat pemahaman siswa, alangkah baikanya apabila siswa diberikan pengalaman langsung untuk menemukan konsep-konsep dari materi pelajaran yang dihadapinya dan dari segi guru, guru juga harus pandai serta teliti dalam memilih media.

Berdasarkan observasi dan wawancara yang dilakukan pada tanggal 7 Februari 2019 dengan semua guru kelas IV Gugus I Mengwi, dikatakan bahwa kompetensi pengetahuan dalam muatan pembelajaran IPA siswa masih belum optimal di setiap kelasnya, dimana siswa tersebut mendapatkan nilai di bawah Kriteria Ketuntasan Minimal (KKM) yaitu 72 (dari hasil rata-rata seluruh KKM IPA di Gugus I Mengwi). Untuk kompetensi pengetahuan pada muatan pembelajaran IPA diperoleh dari nilai Ulangan Akhir Semester I yaitu, dari 187 siswa yang mendapat nilai A sebanyak 33 siswa, siswa yang mendapat nilai B sebanyak 53 siswa, siswa yang mendapat nilai C sebanyak 83 siswa, dan siswa yang mendapat nilai D sebanyak 18 siswa. Pencapaian nilai yang diharapkan dalam Kurikulum 2013 untuk kompetensi pengetahuan adalah mencapai nilai B. Berdasarkan data yang diperoleh, 86 siswa atau 46\% yang sudah mencapai nilai yang diharapkan. Sedangkan, 101 siswa atau 54\% yang belum mencapai nilai yang diharapkan. Data tersebut tentunya merupakan sebuah permasalahan dalam pelaksanaan kurikulum 2013 dan juga menjadi permasalahan dalam muatan pembelajaran IPA itu sendiri yang pada hakekatnya merupakan mata pelajaran dasar dari seluruh jenjang pendidikan sekolah.

Permasalahan belum optimalnya kompetensi pengetahuan siswa pada muatan pembelajaran IPA seperti yang telah dipaparkan, dapat disebabkan karena beberapa alasan. "Adanya anggapan yang menyatakan IPA merupakan mata pelajaran yang sulit" (Susanto, 2013:165). Selain itu, terdapat juga pemahaman yang salah, dengan menyatakan IPA sebagai pelajaran yang cenderung hafalan, sehingga IPA masih sering dibelajarkan dengan menerapkan metode pembelajaran yang lebih menekankan pada keaktifan guru, bukan keaktifan siswa dan pemberian tes yang memerlukan jawaban bersifat hafalan atau mengulang kembali informasi yang telah dipelajari sebelumnya tanpa memberikan kesempatan pada siswa untuk dapat berpikir dan mengembangkan gagasannya secara lebih mendalam terhadap permasalahan yang disajikan, akibatnya siswa akan mengalami kesulitan untuk mengembangkan berbagai potensi yang dimiliki.

Usaha dalam mengembangkan potensi siswa perlu dilakukan dengan menerapkan sebuah model pembelajaran inovatif dan konstruktif yang dapat meningkatkan keaktifan siswa dalam proses pembelajaran, memaksimalkan interaksi antara komponen pembelajaran, dan meningkatkan kemampuan siswa dalam memahami materi pembelajaran.

Sebagai salah satu alternatif untuk mengatasi kelemahan-kelemahan yang dihadapi guru dalam proses pembelajaran, maka diterapkan model pembelajaran untuk mengoptimalkan proses pembelajaran terhadap kompetensi pengetahuan IPA siswa, yakni model pembelajaran Project Based Learning.

Menurut Isrok'atun dan Rosmala (2018:106) "model Project Based Learning merupakan salah satu model pembelajaran aktif yang berorientasi pada project". Dalam dunia pendidikan, terutama pembelajaran menggunakan project sebagai desain pembelajaran dilakukan dengan penugasan proyek yang harus diselesaikan oleh siswa sehingga menghasilkan produk hasil kegiatan belajar. Menurut Lestari, dkk. (dalam Isrok'atun, 2016:475) "model pembelajaran berbasis proyek menekankan siswa untuk membuat proyek dan menghasilkan produk atau karya, kemudian belajar dari proses pembuatan proyek dan produk tersebut agar materi mudah dipahami”. Hasil produk atau karya siswa dijadikan sebagai alat memahami konsep materi. Langkah demi langkah kegiatan belajar yang dilakukan siswa dalam membuat suatu produk atau karya, menjadi jalan mengkonstruksi suatu materi pelajaran. Siswa yang memahami setiap tahapan yang dilakukan secara mandiri, akan menghasilkan pemahaman konsep materi secara utuh. Penugasan proyek tersebut memperoleh hasil akhir berupa produk ataupun karya siswa. Pembelajaran melalui model Project Based Learning dapat diterapkan sebagai sebuah model belajar untuk mengembangkan kemampuan siswa dalam membuat perencanaan, berkomunikasi, menyelesaikan masalah, dan membuat keputusan. "Dengan model pembelajaran Project Based Learning memungkinkan siswa untuk melakukan aktivitas belajar saintifik berupa kegiatan: 1) bertanya; 2) melakukan pengamatan; 3) melakukan penyelidikan atau percobaan; 4) menalar; dan 5) menjalin hubungan dengan orang lain dalam upaya memperoleh informasi atau data" (Sani, 2014:175). Agar model pembelajaran Project Based Learning benar-benar merupakan kegiatan pembelajaran yang menarik bagi siswa, dan 
siswa bisa melakukannya untuk dapat menambah pengetahuan, untuk itu beberapa sifat proyek harus diperhatikan cara pemilihan bentuk proyeknya. Proyek hendaknya menantang siswa untuk melakukan dan menyelesaikannya. Hasilnya memang sungguh ada gunanya, baik untuk siswa sendiri maupun masyarakat. Proyek ini ada unsur membuat sesuatu atau meneliti sesuatu yang belum biasa dilakukan. Proyek sendiri memungkinkan beberapa siswa untuk bekerja sama secara intensif.

Untuk mendukung penerapan model pembelajaran Project Based Learning tentunya masih membutuhkan kegiatan yang dapat merangsang rasa ingin tahu siswa lebih mendalam dan berperan aktif dalam pembelajaran seperti halnya melalui percobaan sederhana. Melalui percobaan sederhana siswa dapat mempraktekkan secara langsung materi pembelajaran, menemukan sendiri konsep belajar, menjadi sarana memupuk kreatifitas inisiatif kemandirian, kerja sama atau gotong royong dan meningkatkan minat belajar.

Menurut Djamarah dan Zain (2018:84) "percobaan adalah cara penyajian pelajaran, dimana siswa melakukan percobaan dengan mengalami dan membuktikan sendiri sesuatu yang dipelajari”. Percobaan yang dimaksud dalam penelitian ini bukan seperti percobaan yang dilakukan oleh ilmuan-ilmuan, melainkan percobaan yang berkaitan dengan kehidupan siswa SD dan menggunakan alat serta bahan yang sederhana. Sederhana dalam artian murah, berkualitas, dekat dengan kehidupan dan ada di sekitar siswa SD. Sehingga dapat dirangkum bahwa percobaan sederhana adalah serangkaian percobaan yang dilakukan dengan alat atau bahan sederhana, dimana bahan-bahan tersebut bisa dengan mudah didapatkan di alam sekitar siswa. Percobaan sederhana dimaksudkan untuk mengenalkan siswa tentang alam sekitar melalui kegiatan yang dilakukan secara langsung oleh siswa sehingga dapat melatih anak melakukan eksplorasi terhadap berbagai benda di sekitarnya. Siswa akan memperoleh pengetahuan baru dari interaksi dengan berbagai benda yang diobservasinya melalui percobaan sederhana. Percobaan sederhana yang dilakukan di SD pada pembelajaran IPA diharapkan mampu meningkatkan pemahaman mengenai konsep sederhana.

Berdasarkan uraian tersebut, maka akan dilakukan penelitian dengan judul "Pengaruh Model Pembelajaran Project Based Learning Melalui Percobaan Sederhana Terhadap Kompetensi Pengetahuan IPA Kelas IV SD Gugus I Mengwi Tahun Pelajaran 2018/2019".

Adapun tujuan yang ingin dicapai dalam penelitian ini adalah untuk mengetahui pengaruh yang signifikan model pembelajaran Project Based Learning melalui percobaan sederhana terhadap kompetensi pengetahuan IPA kelas IV SD Gugus I Mengwi Tahun Pelajaran 2018/2019.

\section{Metode}

Penelitian ini dilaksanakan di SD Gugus I Mengwi, Kabupaten Badung tahun pelajaran 2018/2019. Adapun waktu penelitian ini dilaksanakan pada bulan April sampai Mei 2019. Perlakuan diberikan sebanyak 6 kali di kelompok eksperimen dan 6 kali di kelompok kontrol.

Penelitian ini merupakan penelitian kuantitatif dengan jenis penelitian yaitu eksperimen semu (quasi experiment). Sugiyono (2012:77) menyatakan "rancangan ini mempunyai kelompok kontrol, tetapi tidak dapat berfungsi sepenuhnya untuk mengontrol variabel-variabel luar yang mempengaruhi pelaksanaan eksperimen". Desain eksperimen yang digunakan dalam penelitian ini adalah Nonequivalent Control Group Design. Dalam rancangan ini ada dua kelompok subjek, satu kelompok mendapat perlakuan dan satu kelompok lagi sebagai kelompok kontrol. Kedua kelompok memperoleh pre-test dan post-test. Pre-test diberikan kepada kelompok kontrol dan kelompok eksperimen. Pemberian pre-test ini digunakan untuk mengetahui apakah sampel yang terpilih sudah setara atau tidak. Sejalan dengan hal tersebut, Dantes (2012:97) menyatakan "pemberian pre-test biasanya digunakan untuk mengukur equivalensi atau penyetaraan kelompok". Setelah diberikan pre-test dan dapat dinyatakan setara, kemudian diberikan perlakuan dalam pembelajaran yaitu memberikan perlakuan dengan model pembelajaran Project Based Learning melalui percobaan sederhana kepada kelompok eksperimen dan kelompok kontrol dibelajarkan dengan pembelajaran konvensional. Setelah diberikan perlakuan, dilakukan post-test untuk mengetahui penguasaan kompetensi pengetahuan IPA siswa. Pelaksanaan eksperimen dalam penelitian ini terdiri dari tiga tahapan yaitu, (1) tahap persiapan eksperimen, (2) tahap pelaksanaan eksperimen, dan (3) tahap akhir eksperimen.

Populasi dalam penelitian ini adalah seluruh kelas IV SD Gugus I Mengwi tahun pelajaran 2018/2019, yang terdiri dari 6 kelas dalam 6 sekolah dasar. Jumlah populasi dari penelitian ini adalah sebanyak 187 siswa.

Teknik pengambilan sampel yang digunakan dalam penelitian ini adalah random sampling. Teknik random sampling adalah pengambilan sampling secara random atau tanpa pandang bulu. Teknik ini memiliki kemungkina tertinggi dalam menetapkan sampel yang representatif. "Pada teknik ini semua 
individu dalam populasi diberi kesempatan yang sama untuk dipilih menjadi anggota sampel" (Sumarni, 2012:114). Untuk menentukan sampel, cara yang digunakan adalah dengan melakukan pengundian kelas. Berdasarkan hasil undi, kelas IV SD No. 1 Pererenan dengan jumlah siswa sebanyak 32 orang siswa yang muncul pertama dijadikan sebagai kelompok eksperimen sedangkan kelas IV SD No. 1 Cemagi dengan jumlah siswa sebanyak 30 orang siswa yang muncul kedua dijadikan sebagai kelompok kontrol. Untuk mengetahui kesetaraan dari segi akademis, kedua sampel tersebut diberikan pre-test. Skor hasil pre-test kemudian dianalisis dengan menggunakan uji-t yakni rumus polled varians. Kriteria pengujian, jika $t_{\text {hitung }}>$ $t_{\text {tabel}}$, maka $\mathrm{H}_{\mathrm{o}}$ ditolak dan $\mathrm{H}_{\mathrm{a}}$ diterima sehingga kelompok tidak setara. Jika $\mathrm{t}_{\text {hitung }} \leq \mathrm{t}_{\text {tabel, }}$ maka $\mathrm{H}_{\mathrm{o}}$ diterima dan $\mathrm{H}_{\mathrm{a}}$ ditolak sehingga kelompok setara. Pada taraf signifikansi $5 \%$ dengan $\mathrm{dk}=\mathrm{n}_{1}+\mathrm{n}_{2}-2$.

Namun sebelum dilakukan uji kesetaraan, terlebih dahulu dilakukan uji prasyarat analisis yang meliputi uji normalitas dengan menggunakan tabel Kolmogorov-Smirnov dan uji homogentitas dengan menggunakan uji Fisher dari Harthley.

Berdasarkan perhitungan hasil uji normalitas sebaran data skor pre-test pada kelompok eksperimen, diperoleh $D_{\text {hitung }}=0,1337$ dengan $D_{\text {tabel }}=0,2300$, karena $D_{\text {hitung }}=0,1337<D_{\text {tabel }}=0,2300$ maka data berdistribusi normal. Sedangkan berdasarkan perhitungan hasil uji normalitas sebaran data skor pretest pada kelompok kontrol, diperoleh $D_{\text {hitung }}=0,1279$ dengan $D_{\text {tabel }}=0,2400$, karena $D_{\text {hitung }}=0,1279<$ $\mathrm{D}_{\text {tabel }}=0,2400$ maka data berdistribusi normal.

Setelah dianalisis menggunakan uji normalitas, selanjutnya dilakukan uji homogenitas. Berdasarkan hasil uji homogenitas, diperoleh $F_{\text {hitung }}=1,18$ dengan $F_{\text {tabel }}(\alpha=0,05)=1,85$, karena $F_{\text {hitung }}<F_{\text {tabel }}$ $(1,18<1,85)$, maka data hasil skor pre-test siswa antara kelompok eksperimen dan kelompok kontrol memiliki varians yang homogen.

Setelah dilakukan uji prasyarat, dapat diketahui bahwa data hasil pre-test pada kedua sampel telah berdistribusi normal dan homogen. Sehingga dapat dilanjutkan dengan uji kesetaraan yaitu menggunakan uji-t. Berdasarkan hasil analisis, diketahui bahwa $\mathrm{t}_{\text {hitung }}=0,139<\mathrm{t}_{\text {tabel }}=2,000$ pada taraf signifikansi $5 \%$ dengan $d k=32+30-2=60$. Dengan demikian, maka kedua sampel penelitian dapat dinyatakan setara. Setelah dinyatakan setara, kelompok eksperimen diberikan perlakuan dengan menggunakan model pembelajaran Project Based Learning melalui percobaan sederhana dan pada kelompok kontrol dengan pembelajaran konvensional.

Data yang dikumpulkan pada penelitian ini meliputi data tentang kompetensi pengetahuan IPA pada siswa kelas IV SD Gugus I Mengwi tahun pelajaran 2018/2019 yang merupakan kelompok sampel. Data tersebut diperoleh dengan menggunakan metode tes. Instrumen pengumpulan data dalam penelitian ini menggunakan tes objektif dalam tampilan pilihan ganda biasa yang dilengkapi dengan 4 pilihan jawaban (a, b, c, dan d). Instrumen yang telah dibuat kemudian diuji secara teoretik oleh para ahli (expert judgement) di bidang IPA. Selanjutnya, instrumen yang telah mendapat pertimbangan oleh pakar kemudian diujicobakan untuk mendapatkan gambaran secara empirik mengenai kelayakan instrumen melalui uji validitas butir tes, uji daya beda, uji taraf kesukaran, dan uji reliabilitas. Dari 50 butir soal, dinyatakan 30 butir soal yang layak digunakan sebagai instrumen penelitian untuk soal pre-test dan soal post-test.

Setelah data dikumpulkan, data tersebut perlu dianalisis. Teknik analisis data yang digunakan untuk menganalisis data dalam penelitian ini adalah teknik analisis statistik inferensial. Pada penelitian ini sebelum analisis data melalui statistik inferensial dilakukan, terlebih dahulu hasil pre-test dan post-test pada kedua kelompok sampel dalam penelitian ini dinormalisasi dengan menggunakan gain skor ternormalisasi. Adapun rumus gain skor ternormalisasi sebagai berikut.

$$
G S n=\frac{\text { Gain Skor }}{\text { Skor Max-Skor Pretest }}
$$

(Dantes, 2014:126)

\author{
Keterangan: \\ GSn $\quad=$ Gain skor ternormalisasi \\ Gain Skor = Skor posttest-prestest
}

Analisis inferensial dapat dilakukan dengan menggunakan statistik parametris yaitu menggunakan teknik uji-t ( $t$-test) dengan rumus polled varians. Rumus ini digunakan untuk menguji hipotesis karena jumlah anggota sampel tidak sama $\left(\mathrm{n}_{1} \neq \mathrm{n}_{2}\right)$ dan memiliki varians homogen. Sebelum melakukan uji hipotesis harus dilakukan uji prasyarat terlebih dahulu yang meliputi uji normalitas dengan menggunakan tabel Kolmogorov-Smirnov dan uji homogentitas dengan menggunakan uji Fisher dari Harthley. 
Adapun hipotesis penelitian yang diuji yaitu Ho: tidak terdapat perbedaan yang signifikan kompetensi pengetahuan IPA antara kelompok siswa yang dibelajarkan dengan model pembelajaran Project Based Learning melalui percobaan sederhana dengan kelompok siswa yang dibelajarkan secara konvensional pada siswa kelas IV SD Gugus I Mengwi tahun pelajaran 2018/2019. Hipotesis statistik yang diuji dalam penelitian ini adalah:

$\mathrm{H}_{\mathrm{o}} \quad: \mu_{1}=\mu_{2}$

(Sugiyono, 2012:163)

Oleh karena data yang diperoleh telah memenuhi prasyarat uji normalitas sebaran data dan homogenitas varians maka analisis yang digunakan adalah statistik parametrik. Analisis statistik yang digunakan untuk menguji hipotesis penelitian ini adalah uji beda mean (uji-t). Uji Hipotesis menggunakan uji-t dengan rumus polled varians. Rumus uji-t dengan rumus polled varians digunakan bila jumlah anggota sampel sama $\mathrm{n}_{1}=\mathrm{n}_{2}$ dan varians homogen. Rumus uji-t dengan rumus polled varians sebagai berikut.

$$
t=\frac{\bar{X}_{1}-\bar{X}_{2}}{\sqrt{\frac{\left(n_{1}-1\right) s_{1}^{2}+\left(n_{2}-1\right) s_{2}^{2}}{n_{1}+n_{2}-2}\left(\frac{1}{n_{1}}+\frac{1}{n_{2}}\right)}}
$$

Keterangan:

(Sugiyono, 2012:197)

$$
\begin{array}{ll}
\bar{X}_{1} & =\text { rata-rata nilai akhir kelompok eksperimen } \\
\bar{X}_{2} & =\text { rata-rata nilai akhir kelompok kontrol } \\
S_{1}^{2} & =\text { varians sampel kelompok eksperimen } \\
S_{2}^{2} & =\text { varians sampel kelompok kontrol } \\
n_{1} & =\text { jumlah siswa kelompok eksperimen } \\
n_{2} & =\text { jumlah siswa kelompok kontrol }
\end{array}
$$

Dengan kriteria pengujian, jika $t_{\text {hitung }} \leq \mathrm{t}_{\text {tabel, }}$ maka $\mathrm{H}_{0}$ diterima dan $\mathrm{H}_{\mathrm{a}}$ ditolak sehingga kelompok setara. Jika $t_{\text {hitung }}>t_{\text {tabel, }}$ maka $\mathrm{H}_{0}$ ditolak dan $\mathrm{H}_{\mathrm{a}}$ diterima sehingga kelompok tidak setara. Pada taraf sifnifikasi $5 \%$ dengan $\mathrm{dk}=\mathrm{n}_{1}+\mathrm{n}_{2}-2$.

\section{Hasil Dan Pembahasan}

Kelompok eksperimen dalam penelitian ini adalah kelas IV SD No. 1 Pererenan yang berjumlah 32 orang siswa. Setelah diberikan pre-test yang dilanjutkan dengan pemberian perlakuan menggunakan model pembelajaran Project Based Learning melalui percobaan sederhana sebanyak 6 kali pertemuan dan kemudian diakhiri dengan memberikan post-test, maka dapat diperoleh data GSn dari skor pre-test dan post-test kompetensi pengetahuan IPA. Dari data GSn kompetensi pengetahuan IPA siswa yang dibelajarkan dengan menggunakan model pembelajaran Project Based Learning melalui percobaan sederhana menunjukkan bahwa skor tertinggi adalah 0,71 dan skor terendah adalah 0,30. Berdasarkan data tersebut, maka dapat dideskripsikan sebagai berikut.

Tabel 01. Deskripsi Rekapitulasi Data Gain Skor Kompetensi Pengetahuan IPA Kelompok Eksperimen

\begin{tabular}{cc}
\hline Data & Kelompok Eksperimen \\
\hline Mean & 0,45 \\
Standar Deviasi & 0,12 \\
Varians & 0,01 \\
Skor Minimum & 0,29 \\
Skor Maksimum & 0,71 \\
\hline
\end{tabular}


Kelompok kontrol dalam penelitian ini adalah kelas IV SD No. 1 Cemagi yang berjumlah 30 orang siswa. Setelah diberikan pre-test yang dilanjutkan dengan pelaksanaan pembelajaran dengan menggunakan pembelajaran konvensional sebanyak 6 kali pertemuan dan kemudian diakhiri dengan memberikan post-test, maka dapat diperoleh data GSn dari skor pre-test dan post-test kompetensi pengetahuan IPA. Dari data GSn kompetensi pengetahuan IPA siswa yang dibelajarkan dengan menggunakan pembelajaran konvensional menunjukkan bahwa skor tertinggi yang diperoleh adalah 0,50 dan skor terendah adalah 0,15. Berdasarkan data tersebut, maka dapat dideskripsikan sebagai berikut.

Tabel 02. Deskripsi Rekapitulasi Data Gain Skor Kompetensi Pengetahuan IPA Kelompok Kontrol

\begin{tabular}{cc}
\hline Data & Kelompok Kontrol \\
\hline Mean & 0,32 \\
Standar Deviasi & 0,09 \\
Varians & 0,01 \\
Skor Minimum & 0,15 \\
Skor Maksimum & 0,50 \\
\hline
\end{tabular}

Selanjutnya sebelum melakukan uji hipotesis, dilakukan uji prasyarat yang meliputi normalitas sebaran data dengan menggunakan tabel Kolmogorov-Smirnov dan uji homogenitas dengan menggunakan uji Fisher dari Harthley.

Berdasarkan perhitungan hasil uji normalitas sebaran data GSn kompetensi pengetahuan IPA pada kelompok eksperimen, diperoleh $D_{\text {hitung }}=0,1516$ dengan $D_{\text {tabel }}=0,2300$, karena $D_{\text {hitung }}=0,1516<\mathrm{D}_{\text {tabel }}=$ 0,2300 maka data berdistribusi normal. Sedangkan berdasarkan perhitungan hasil uji normalitas sebaran data GSn kompetensi pengetahuan IPA pada kelompok kontrol, diperoleh $D_{\text {hitung }}=0,1587$ dengan $D_{\text {tabel }}=$ 0,2400 , karena $D_{\text {hitung }}=0,1587<D_{\text {tabel }}=0,2400$ maka data berdistribusi normal.

Berdasarkan hasil uji homogenitas data GSn kompetensi pengetahuan IPA pada kelompok eksperimen dan kelompok kontrol, dapat diperoleh $\mathrm{F}_{\text {hitung }}=1,63$ dengan $\mathrm{F}_{\text {tabel }(\alpha=0,05)}=1,85$, karena $\mathrm{F}_{\text {hitung }}<$ $F_{\text {tabel, }}$ maka data GSn kompetensi pengetahuan IPA antara kelompok eksperimen dan kelompok kontrol mempunyai varians yang homogen.

Setelah dilakukan uji prasyarat, dapat diketahui bahwa data GSn kompetensi pengetahuan IPA siswa pada kelompok eksperimen dan kelompok kontrol telah berdistribusi normal dan memiliki varians yang homogen. Sehingga dapat dilanjutkan dengan melakukan uji hipotesis statistik yaitu menggunakan uji-t. Adapun rekapitulasi hasil analisis uji-t dari data GSn kompetensi pengetahuan IPA siswa pada kelompok eksperimen dan kelompok kontrol adalah sebagai berikut.

Tabel 03. Rekapitulasi Hasil Uji Hipotesis Berdasarkan Data GSn Kompetensi Pengetahuan IPA

\begin{tabular}{lccrcccc}
\hline \multicolumn{1}{c}{ Sampel Penelitian } & $\mathbf{N}$ & $\mathbf{d k}$ & $\bar{x}$ & $\mathbf{s}^{\mathbf{2}}$ & $\mathbf{t}_{\text {hitung }}$ & $\mathbf{t}_{\text {tabel }}$ & Keterangan \\
Kelompok Eksperimen & 32 & & 0,45 & 0,01 & & & \\
Kelompok Kontrol & 30 & & 0,32 & 0,01 & & & \\
\end{tabular}

Berdasarkan hasil analisis uji hipotesis, diperoleh $t_{\text {hitung }}=5,139$ dan $t_{\text {tabel }}=2,000$ yaitu pada taraf signifikansi $5 \%$ dengan $d k=32+30-2=60$. Sehingga dapat diketahui bahwa $t_{\text {hitung }}=5,139>t_{\text {tabel }}=$ 2,000. Dengan demikian, maka $\mathrm{H}_{0}$ ditolak yang menyatakan tidak terdapat perbedaan yang signifikan kompetensi pengetahuan IPA antara kelompok siswa yang dibelajarkan menggunakan model pembelajaran Project Based Learning melalui percobaan sederhana dengan kelompok siswa yang dibelajarkan menggunakan pembelajaran konvensional pada siswa kelas IV di SD Gugus I Mengwi tahun pelajaran 2018/2019 dan $\mathrm{H}_{\mathrm{a}}$ diterima yang menunjukkan bahwa terdapat perbedaan yang signifikan kompetensi pengetahuan IPA antara kelompok siswa yang dibelajarkan menggunakan model pembelajaran Project Based Learning melalui percobaan sederhana dengan kelompok siswa yang dibelajarkan menggunakan pembelajaran konvensional pada siswa kelas IV di SD Gugus I Mengwi tahun pelajaran 2018/2019.

Mengenai hasil penelitian yang diperoleh dari kelompok eksperiemen yang dibelajarkan menggunakan model pembelajaran Project Based Learning melalui percobaan sederhana dan kelompok kontrol yang dibelajarkan secara konvensional, kedua kelompok tersebut diketahui memiliki kemampuan 
awal yang sama atau setara berdasarkan pada analisis data hasil pre-test. Kemudian perlakuan berupa model pembelajaran Project Based Learning melalui percobaan sederhana hanya diberikan kepada kelompok eksperimen sebanyak 6 kali pertemuan, dan setelah perlakuan tersebut kedua kelompok diberikan post-test untuk mendapatkan data kompetensi pengetahuan IPA siswa.

Melalui analisis data GSn kompetensi pengetahuan IPA siswa kelompok eksperimen dan kelompok kontrol yang berdasarkan pada skor pre-test dan skor post-test, maka diperoleh $t_{\text {hitung }}=5,139$ dan $t_{\text {tabel }}=$ 2,000 yaitu pada taraf signifikansi $5 \%$ dengan $d k=32+30-2=60$. Sehingga dapat diketahui bahwa $t_{\text {hitung }}=5,139>t_{\text {tabel }}=2,000$. Dengan demikian, maka $H_{o}$ ditolak. Hal ini menunjukkan bahwa terdapat perbedaan yang signifikan kompetensi pengetahuan IPA antara kelompok siswa yang dibelajarkan menggunakan model pembelajaran Project Based Learning melalui percobaan sederhana dengan kelompok siswa yang dibelajarkan secara konvensional pada kelas IV di SD Gugus I Mengwi tahun pelajaran 2018/2019.

Pada perolehan hasil perhitungan analisis data menunjukkan bahwa rata-rata data GSn kompetensi pengetahuan IPA siswa pada kelompok eksperimen yaitu $\bar{X}=0,45$ lebih dari rata-rata pada kelompok kontrol yaitu $\bar{X}=0,32$. Hal ini menunjukkan bahwa kompetensi pengetahuan IPA pada kelompok siswa yang dibelajarkan menggunakan model pembelajaran Project Based Learning melalui percobaan sederhana lebih baik daripada kelompok siswa yang dibelajarkan menggunakan pembelajaran konvensional. Dengan demikian dapat dikatakan bahwa terdapat pengaruh model pembelajaran Project Based Learning melalui percobaan sederhana terhadap kompetensi pengetahuan IPA pada kelas IV di SD Gugus I Mengwi tahun pelajaran 2018/2019.

Berdasarkan hasil temuan tersebut, dapat dinyatakan kedua kelompok sampel penelitian yang memiliki kemampuan setara, setelah diberikan perlakuan berupa pembelajaran dengan menggunakan model pembelajaran Project Based Learning melalui percobaan sederhana dan mengikuti pembelajaran menggunakan pembelajaran konvensional diperoleh kompetensi pengetahuan IPA yang berbeda. Perbedaan yang signifikan kompetensi pengetahuan IPA siswa pada kelompok eksperimen dan kelompok kontrol tersebut disebabkan karena pembelajaran dengan menerapkan model Project Based Learning pada kelompok eksperimen memberikan kesempatan yang lebih banyak kepada siswa untuk mengkostruksi atau membentuk pemahamannya sendiri terhadap konsep pelajaran dengan membuat suatu produk atau karya. Dalam pembuatan karya tersebut, kolaborasi antara pemahaman (pengetahuan) dan keterampilan siswa memiliki porsi yang relatif berimbang sehingga penerapan model Project Based Learning melalui percobaan sederhana tidak hanya dapat dirasakan oleh siswa yang pandai dalam segi kognitif saja tetapi juga siswa yang lemah dalam segi kognitif tetapi memiliki keterampilan untuk membuat karya.

Anak usia sekolah dasar dalam perkembangannya berada dalam tahap operasional konkret sehingga sebaiknya disajikan pembelajaran yang mengedepankan objek-objek nyata sebagai media pembelajarannya. Percobaan sederhana yang diterapkan dalam model Project Based Learning sangat membantu siswa dalam mempraktekkan suatu kegiatan yang terkait dengan alam dalam pembelajaran IPA, sehingga dapat membantu pemahaman siswa dalam merencanakan proyek yang mereka buat. Hal tersebut sejalan dengan pendapat Djamarah (2018:84) yang menyatakan "salah satu kelebihan melakukan percobaan sederhana adalah dapat membina siswa untuk membuat terobosan-terobosan baru dengan penemuan dari hasil percobaannya dan bermanfaat bagi kehidupan manusia". Melalui percobaan sederhana ini, siswa merasa lebih mudah untuk mengingat materi pembelajaran dan memahami konsep materi alam yang hampir sebagian besar bersifat hafalan.

Dalam pembuatan proyek, siswa terlibat aktif dalam perencanaan dan kerjasama dalam kelompok. Siswa diberikan kesempatan secara aktif untuk menuangkan ide-ide yang mereka punya dalam sebuah karya yang menarik. Guru berperan sebagai fasilitator siswa, sehingga pembelajaran berpusat pada siswa (student centered). Siswa lebih antusias dalam membuat hal-hal baru yang belum pernah mereka kerjakan, sehingga lebih mengundang rasa ingin tahu siswa dan dapat lebih memotivasi siswa dalam belajar. Selain itu, anak usia sekolah dasar tidak hanya harus dibebani materi-materi yang sifatnya teoretis saja. Pengajaran perlu disisipkan hal-hal tertentu yang dapat merangsang pikiran siswa agar materi yang diajarkan dapat menarik bagi siswa. Dalam hal ini pembelajaran model Project Based Learning melalui percobaan sederhana mempunyai peranan yang tepat untuk membangkitkan motivasi serta menanamkan pengetahuan secara efektif melalui pembuatan suatu produk atau karya. Pembelajaran Project Based Learning ini mengajak siswa untuk berlatih merencanakan sesuatu, mengolah sumber belajar, dan memutuskan suatu hal melalui kerjasama dalam kelompok. Hal tersebut dapat membentuk karakter siswa dalam bekerjasama dengan kelompok sehingga pembelajaran lebih bermakna. 
Berbeda dengan pembelajaran yang berlangsung pada kelompok kontrol. Kegiatan pembelajaran pada kelompok kontrol berjalan kurang optimal, karena hanya menerapkan pembelajaran konvensional dengan pendekatan saintifik. Pedekatan saintifik yang dimaksud yaitu pembelajaran yang tidak menerapkan sintak belajar, namun menggunaka lima pengalaman belajar yaitu mengamati, menanya, mengumpulkan informasi, mengasosiasi, dan mengkomunikasikan, yang pelaksanaanya tidak tersusun secara sistematis. Hal tersebut membuat pembelajaran terasa monoton, sehingga siswa menjadi kurang aktif dalam proses pembelajaran. Selain itu, juga mengakibatkan siswa terlihat kurang bersemangat serta kurang antusias dalam mengikuti pembelajaran yang tengah berlangsung. Pembelajaran seperti ini, membuat siswa merasa bosan dan jenuh dalam mengikuti pembelajaran, karena merasa bosan pembelajaran tidak dapat dipahami siswa sehingga pembelajaran menjadi kurang bermakna.

Hasil penelitian ini memperkuat simpulan yang disampaikan oleh Dewi (2017) yang menyatakan bahwa model Project Based Learning berpengaruh terhadap hasil belajar IPA siswa kelas V SD di Gugus II Kecamatan Mengwi tahun ajaran 2016/2017. Selanjutnya penelitian dari Dewi (2018) menyatakan bahwa model pembelajaran Project Based Learning berpengaruh terhadap komptensi pengetahuan IPA kelas V SD Gugus II Kuta Utara tahun ajaran 2017/2018.

Dengan demikian, pembelajaran menggunakan model pembelajaran Project Based Learning melalui percobaan sederhana pada penelitian ini memiliki keunggulan yakni pembelajaran lebih menyenangkan dan tidak membosankan karena siswa dapat menemukan sendiri konsep dari materi yang dipelajari, hubungan atara siswa dengan guru, siswa dengan siswa akan lebih akrab, membuat siswa untuk mengembangkan kreativitas, kemampuan, dan daya pemecahan masalah, lebih mudah memahami dan lama mengingat pembelajaran karena mempraktekan langsung, memiliki rasa ingin tahu yang tinggi, dan mampu bekerjasama dalam kelompok.

Berdasarkan pemaparan tersebut, dapat dirangkum bahwa model pembelajaran Project Based

Learning melalui percobaan sederhana berpengaruh terhadap kompetensi pengetahuan IPA kelas IV

SD Gugus I Mengwi Tahun Pelajaran 2018/2019.

\section{Simpulan Dan Saran}

Berdasarkan hasil penelitian dan pembahasan, maka dapat ditarik simpulan yaitu melalui hasil analisis data GSn kompetensi pengetahuan IPA pada kelompok eksperimen dan kelompok kontrol dengan menggunakan uji $t$, diperoleh $t_{\text {hitung }}=5,139$, dan $t_{\text {tabel }}=2,000$ pada taraf signifikasi $5 \%$ dengan dk $=60$. Oleh karena $t_{\text {hitung }}=5,139>t_{\text {tabel }}=2,000$, maka $H_{o}$ ditolak. Hasil ini menunjukkan bahwa terdapat perbedaan yang signifikan kompetensi pengetahuan IPA antara kelompok siswa yang dibelajarkan menggunakan model pembelajaran Project Based Learning melalui percobaan sederhana dengan kelompok siswa yang dibelajarakan menggunakan pembelajaran konvensional pada kelas IV SD Gugus I Mengwi tahun pelajaran 2018/2019. Berdasarkan hasil analisis tersebut, diketahui bahwa rata-rata data GSn kompetensi pengetahuan IPA pada kelompok eksperimen lebih dari nilai rata-rata kelompok kontrol yaitu $X_{1}=0,45>X_{2}=0,32$. Dengan demikian dapat dikatakan bahwa terdapat pengaruh yang signifikan model pembelajaran Project Based Learning melalui percobaan sederhana terhadap kompetensi pengetahuan IPA kelas IV SD Gugus I Mengwi tahun pelajaran 2018/2019.

Berdasarkan hasil penelitian dan simpulan, dapat disarankan kepada: (1) Guru, agar lebih kreatif untuk memberikan fasilitas berupa sumber belajar dan kesempatan yang lebih besar bagi siswa pada pembelajaran dengan menggunakan model pembelajaran Project Based Learning melalui percobaan sederhana dan dapat dijadikan alternatif dalam proses pembelajaran untuk membantu siswa meningkatkan kompetensi pengetahuan IPA dengan maksimal, (2) Kepala Sekolah, agar dapat menggunakan hasil penelitian ini sebagai alternatif dalam mengelola pembelajaran agar sesuai dengan karakteristik pembelajaran IPA, sehingga mampu meningkatkan pengetahuan dan pemahaman siswa tentang IPA, (3) Peneliti Lain, hendaknya hasil penelitian ini dapat dijadikan kajian penelitian relevan. Sebagai penunjang penelitian dengan kajian yang lebih luas dan mendalam mengenai model pembelajaran Project Based Learning melalui percobaan sederhana dalam kaitannya dengan hasil belajar baik kompetensi pengetahuan, sikap, maupun keterampilan.

\section{Daftar Rujukan}

Badar, Trianto Ibnu. 2014. Mendesain Model Pembelajaran Inovatif, Progresif, dan Kontekstual. Jakarta: Pranamedia Group

Dantes, Nyoman. 2012. Metode Penelitian. Yogyakarta: CV. Andi Offset. 
Dantes, Nyoman. 2014. Desain Eksperimen dan Analisis Data. Jakarta: PT. Raja Grafindo Persada.

Daryanto. 2014. Pendekatan Pembelajaran Saintifik Kurikulum 2013. Yogyakarta: Gava Media.

Daryanto dan Sudjendro. 2014. Siap Menyongsong Kurikulum 2013. Yogyakarta: Gava Media.

Dewi, Chyntia. 2017. "Pengaruh Model Project Based Learning Berbasis Outdoor Study Terhadap Hasil Belajar IPA Siswa Kelas $V^{\prime \prime}$. Jurnal Pendidikan dan Pengajaran. Volume 5. (https://ejournal.undiksha.ac.id/index.php/JPGSD/article/download/10738/6844) Diakses tanggal 3 Januari 2019.

Dewi, Eri Kumala. 2018. "Pengaruh Model Pembelajaran Project Based Learning Berbantuan Media Outdoor Terhadap Kompetensi Pengetahuan IPA Kelas V SD”. Jurnal Pendidikan dan Pengajaran. Volume 1. (https://ejournal.undiksha.ac.id/index.php/JLLS/article/download/14716/9017) Diakses tanggal 3 Januari 2019.

Djamarah dan Zain. 2018. Strategi Belajar Mengajar. Jakarta: Rineka Cipta.

Isrok'atun dan Rosmala. 2018. Model-Model Pembelajaran Matematika. Jakarta: PT Bumi Aksara.

Sani, Ridwan Abdullah. 2014. Pembelajaran Saintifik untuk Implementasi Kurikulum 2013. Jakarta: Bumi Aksara.

Sugiyono. 2012. Metode Penelitian Kuantitatif Kualitatif Dan R\&D. Bandung: Alfabeta.

Sumarni, Sri. 2012. Metode Penelitian Pendidikan. Yogyakarta: Insan Madani.

Susanto, Ahmad. 2013. Pengembangan Pembelajaran IPS di SD. Jakarta: Predana Media Group.

Undang-Undang No. 20 Tahun 2003 Bab II Pasal 3. 2003. Sistem Pendidikan Nasional. Jakarta: Sisdiknas 